\section{E-LOGOS}

ELECTRONIC JOURNAL FOR PHILOSOPHY ISSN 1211-0442

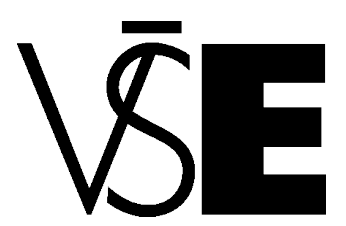

University of Economics

Prague

\title{
O společenských vědách bez identity
}

\author{
Kamil Fleissner
}




\begin{abstract}
This essay aims to discuss the concept of identity in critical perspective and in a wider context of the demarcation problem in social science. Following the famous paper Beyond "Identity" (Brubaker, Cooper: 2000) I submit the question whether the "identity" is still usefull and suited as an analytical tool in social science. I pay attention to the origin of the concept of identity and I compare its essentialist, constructivist and deconstructivist approaches that represent various attitudes to social reality, to knowledge (episteme/doxa) and to relation between science and nonscience. I reflect critically all these three approaches and I argue for replacement of the concept of identity but also for more (auto)critical perception in respect of used research tools and of researchers themselves.
\end{abstract}

Keywords: Identity, demarcation problem, role of social sciences.

\begin{abstract}
Abstrakt
Předkládaná esej se snaží představit koncept identity v kritické perspektivě a v širším kontextu problému demarkace v sociálních vědách. V souladu se známou statí Beyond "Identity“ (Brubaker, Cooper) si pokládám otázku, zda je koncept identity nadále užitečný a vhodný coby analytický nástroj ve společenských vědách. Pozornost věnuji jak samotnému zanesení konceptu na pole sociálních věd, tak i srovnání a zhodnocení esencialistického, konstruktivistického a dekonstruktivistického pojetí, přičemž tyto tři způsoby uchopení daného pojmu vnímám zároveň jako reprezentace různých postojů k sociální realitě, k možnosti skutečného poznání (episteme/doxa) a ke vztahu vědeckého a nevědeckého pole. Kriticky reflektuji všechna tři pojetí a argumentuji ve prospěch nahrazení konceptu identity, avšak také ve prospěch posílení (auto)kritického vnímání ve spojitosti k užívaným vědeckým konceptům a nástrojům, jakožto i k vědcům samotným.
\end{abstract}

Klíčová slova: Identita, problém demarkace, úloha společenských věd 


\section{Identita jakožto společenskovědní koncept}

Při zevrubněǰši rešerši mnoha odborných textů posledních dekád by mohl člověk až nabýt přesvědčení, že si společenské vědy po Třídě, Rase a Národu stvořily další ze svých velkých bohyňs janusovskou tvář́ přirozenosti a falešnosti a nazvaly ji Identita. A jak už to tak u božstva obdobného ražení bývá, je zprvu pro svou podstatu nekriticky uctíváno, později je o něm coby o společenském mýtu pochybováno, až se někteří "heretici“ postupně uvolí a odvážně zvolají „Bůh je mrtev!" a tím načnou období nejistého očekávání, zda se toto sdělení ujme a bude uznáno ve prospěch diskursu nového vědění, nebo nikoliv. Domnívám se, že dnes, čtrnáct let po vydání „kaciřské“ stati Beyond "Identity" od Rogerse Brubakera a Fredericka Coopera, na poli sociálních věd stále tak trochu žijeme onu fázi nejistého očekávání a jsme zúčastněnými svědky paradoxního dění, kdy si sama identita jakožto koncept prochází tím, co jeden z jejích prvních šiřitelů Erik H. Erikson označoval za "krizi identity“ (Erikson, 1963). Identita jakoby se ve světle postmoderní tendence $\mathrm{k}$ (auto)destrukci hranic všech totožností i jinakostí a vlastní neustálé reinterpretace stále častěji ptala sebe sama: „kdo jsem já?“ a nemohla se ztotožnit s proměnlivým, mnohovrstevným a nahodilým obrazem $\mathrm{v}$ zrcadle, které ji z jedné strany nastavují společenské vědy, pro něž je zpravidla sociálním konstruktem, a z druhé strany sama diskursivní a sociálně-kulturní praxe, v níž i nadále přežívají esencialistické tendence vnímat identitu jako zvěcněnou a danou prrirozenost.

Právě v tomto často rozporném vztahu mezi vědeckým a každodenním společenským, neřkuli politickým uchopováním termínu identita a v procesu jeho nezbytného obohacování kategorickými přivlastky (národní, kulturní, etnická, evropská, ženská, kolektivní) lze přitom spatřovat největší slabinu a zároveň možné nebezpečí vyplývající pro sociální praxi. Identita totiž rozhodně není nevinné slovo, které sociálnímu badateli či jinému uživateli slouží čistě k popisu a analýze, ale jde zároveň o performativní koncept podpořený autoritou vědy, jehož užíváním je ve vztahu $\mathrm{k}$ danému kontextu $\mathrm{v}$ jisté míře preskriptivně napomáháno $\mathrm{k}$ vytváření, dotváření či přetváření sociální reality (srov. Austin, 2000; Butler, 1993, 1999; Fulka, 2002). Hovoříme-li nekriticky kupř́kladu o „ženské identitě“, re/produkujeme tak arbitrární konstrukce sociálního vnímání lidských těl, a tím fakticky přistupujeme na postuláty feminismu diference a přispíváme $\mathrm{k}$ naturalizaci a zvěčňování distinkce muž vs. žena (viz Bourdieu, 2000: 11). Vytváŕíme jakýsi imaginární makro-subjekt s "totožnými zkušenostmi“ a "totožnými zájmy“, a tím držíme při životě předsudky s ním spojené; rozehráváme hru sebe-naplňujícího se proroctví. Mám za to, že pojem identita si v sobě nese nemalou míru potenciálu produkovat iluzi „,konečné totality“, o níž hovoří francouzský filozof Emmanuel Lévinas'1, nebot' navzdory opakovanému

\footnotetext{
${ }^{1}$ Emmanuel Levinás (1906 - 1995) ve svém díle "Totalita a nekonečno" poukazuje na tendenci západní filosofie $k$ totalizaci všeho jedinečného pod jediný univerzální pojem, v jehož rámci jedinec ztrácí svůj smysl. Kierkegaard dokonce považuje zestejňující identitu subjektu za démonickou, popírající svobodu
} 
akademickému zdůrazňování, že jde o relačně a situačně podmíněný, proměnlivý a mnohorozměrný sociální konstrukt, je samotný termín „totožnost“ ze sémantického hlediska zestejňujícím a jinakost a proměny popírajícím výrazem, v němž má subjekt při nekritickém zacházení tendenci zanikat ve stejném (totožném), což se následně promítá do sociální a diskursivní praxe - např. v podobě stereotypů a generalizací (srov. Melucci 1995: 46; Olšovský, 2011: 252).

Brubaker a Cooper (2000: 2) v této souvislosti nabízejí řešení spočívající ve vyčlenění „kategorií pro analýzu“ a „kategorií pro praxi“ a volají po vzdání se pojmu identita coby „kategorie pro analýzu“ ve prospěch vhodnějších a flexibilnějších konceptů. ${ }^{2} \mathrm{Na}$ tomto místě je však zcela relevantní položit si otázku, zda toto odloučení zmíněných kategorií a s tím spojené zkonstruování skupiny vyvolených "pojmů pro analýzu“ nemá být spíše dalším $\mathrm{z}$ dokladů domnělé nadřazenosti autority vědy nad

druhého, jiného (Olšovský, 2011: 252). Sám Levinás zvažuje identitu Já ne-esencialisticky jakožto výsledek identifikačních procesů, v rámci nichž Já nezůstává stejné, ale nachází totožnost napříč vším, čím prochází. Já si osvojuje roli subjektu v průběhu přivlastňování okolního světa - v egoismu slasti (Levinás, 1997: 22). Právě pro „identitu“ pojímanou v tomto relativním smyslu užívá v návaznosti na Levináse Paul Ricoeur - reflektující Heideggerův původně hegeliánský koncept Dasein a Meadovo rozlišení subjektu Já (I, ipse) a objektu Já (Me, idem) - výstižnější pojem „ipseita“, tedy vědomí sebe sama (jáství). Identita je oproti tomu plně podmíněna uvědomováním si Já (Me) ze strany „těch druhých“ (viz Ezzy, 1998: 245).

${ }^{2}$ Mezi pojmy, jimiž je možné nahradit koncept identity, zmiňují Brubaker a Cooper (2004: 14 - 21) jako flexibilnější a otevřenější např́ílad pojem (sebe)identifikace a kategorizace. Rozlišují přitom mezi „identifikací s něčím/někým“ (identification with) a „identifikací někoho/něčeho“ (identification to), což koresponduje s klasickým vyčleněním Já ve smyslu subjektu "I" a Mě ve smyslu objektu "Me“. Identifikace pak může mít vztahový (např. relace žák - učitel, matka - dítě) nebo kategorický (klasifikace k určité skupině: národ, etnikum, gender, aj.) charakter. V případě, že se výzkumník snaží zmapovat kategorický identifikační proces ze strany "těch druhých“, tj. snaží se analyzovat jednání jakéhosi identifikátora (toho, kdo identifikuje a označuje - např. státní aparát formující národní vědomí), je pak možné využít foucaltovského konceptu governmentalit (tedy systematizace a racionalizace správy), namísto častého pojetí ",top-down“ konstrukce určité kolektivní identity. V tomto relativně neologickém výrazu se kloubí jak odkaz na technologii ovládání jiných, tak odkaz na technologii sebe samého. Governmentalita je komplexem vědění a moci, jde o způsob regulace a disciplinace společnosti prostřednictvím významového a diskursivního řádu (viz Foucault, 2000 a 2009). Chtějí-li vědci pojmem „identita“ označovat a zdůvodňovat motiv jednání určitých osob, mohou si osvojit konkrétnější pojmy sebe-porozumění a sociální umístění (Brubaker, Cooper, 2004: 14), resp. sociální pole (Bourdieu, 2010); eventuelně mohou používat výstižnější - byt' obdobně komplikovaný termín, s kterým přichází Paul Ricoeur, a sice ipseita, která je přímo spojena s osobní odpovědností a se závazky k určitému konání, které jsou formulovány v jistém společenském kontextu. V případě, že se autoři textů o kolektivitách chtějí věnovat kvalitě představované identity (jakési její domnělé „povaze“), mohou využít některé ze sociologických konceptů kolektivního vědomí (Durkheim, 1926), nebo některé z celé řady historicko-sociologických konceptů kolektivní paměti/zapomínání či tzv. sociálních rámců (Halbwash, 2010; Bergson, 2003; Goffman, 1974; Nora, 2008; Assmann, 2001; Todorov, 1998; Le Goff, 2007; Ricoeur, 2000; aj.). Brubaker s Cooperem (2000: 19) pak v této souvislosti navrhují konkrétní idiomy jako "skupinovost" (groupness), „společnost“" ve smyslu sdílených běžných vlastností (commonality) a "spojitost" (connectedness). Tyto postupně rozšiřující se koncepty reflektují oprávněné přesvědčení, že mít něco s někým společného ještě neznamená, že se tak vytváří určitá skupina s jasnou identitou odlišitelnou od těch druhých; a naopak, že být odlišný apriorně nevylučuje členství v určité skupině či společenství (Novotný, 2010). 
každodenností (viz Paleček, 2008: 65), resp. otázku, do jaké míry je možné stavět sociálního vědce mimo/nad sociální praxi, jejíž je inherentní součástí, nikoliv jejím vnějším pozorovatelem. Společenské vědy nemohou být nikdy zcela objektivní, mohou (a měly by) si však uchovávat dostatečnou míru autonomie (Barša, 2006 : 21). Je tedy možné vnímat Brubakerovu a Cooperovu výzvu k zařazení pojmu identita výlučně do "kategorie pro praxi“ jako chvályhodné úsilí o jistou demarkaci a zvýraznění sociálně-vědní autonomie, nebo spíše jako snahu o přiživení mýtu o posvátnosti (společenských) věd?3

\section{Identita identity}

Již v roce 1983 si Philip Gleason položil ve svém textu „Identifying Identity: A Semantic History“ nikoliv nedůležitou otázku, odkud se začal šířit ve společenských vědách pojem identita a proč si postupně vydobyl takovou oblibu (Gleason, 1983: 926). $\mathrm{V}$ této souvislosti poukazuje na několik podstatných aspektů spojených s kontextem společenských věd po druhé světové válce $\left.{ }^{4}: 1\right)$ diskreditace mnoha sociálně-vědních konceptů, jejichž „užitek“ kulminoval ve třicátých letech 20. století (rasa, národ, charakter); 2) marxisticko-freudovská kritika konceptu masové společnosti ze strany „frankfurtské školy“ a obrat zejména amerických badatelů ke zkoumání individualismu ${ }^{5}$; 3) naléhavá potřeba zkoumat ve světle nedávné zkušenosti s nacismem vztah jedince a společnosti, který se stal novou badatelskou výzvou (Gleason, 1983: 926 - 928). Nemalou roli pak bezpochyby hrálo i poválečné oslabení (dříve naturalizované) jistoty příslušnosti jedince $\mathrm{k}$ určité kolektivitě, což navozovalo existenciální otázky „kdo jsem?“, ",ke komu patřím?“, které prosakovaly do filosofie, umění a v neposlední řadě i do vědy. Reflexe právě uvedených aspektů se pak stala zdrojnicí odborných textů jako „Protestant-Catholic-Jew" Willa Herberta, "The Search of Southern Identity“ C. Vann Wodwarda a konečně i díla "Childhood and Society", kde již zmiňovaný Erik H. Erikson zmapoval problematiku tzv. „krize identity“ v průběhu

\footnotetext{
${ }^{3}$ Velmi kriticky se staví $\mathrm{k}$ otázce glorifikace a živení domnělé nadřazenosti a posvátnosti vědy nad ostatními sférami života např́klad „epistemologický anarchista“ a Popperův žák Paul Karl Feyerabend, který ve svém slavném díle "Rozprava proti metodě" polemizuje s tradičním pohledem na vědu a její metody a v postmoderním duchu ve své práci rozvijí čtyři základní teze: 1) vědecké metodologie neposkytují pravidla vhodné $\mathrm{k}$ vědecké práci (pokrok není výsledkem racionálního jednání); 2) nesrovnatelnost jednotlivých teorií; 3) vědecké znalosti nejsou nadřazeny jinému vědění; 4) zřeknutí se konvenčních metodologických postupů přináší badateli svobodu a podněcuje jeho tvořivost (Feyerabend, 2001: 249).

${ }^{4}$ Gleason (1983: 910) uvádí, že ještě v roce 1930 figuroval v encyklopedii International Encyclopedy of Social Science pouze pojem "identifikace“, a sice v souvislosti s technikami kriminalistického vyšetřování. Termín „identita“ byl do téže encyklopedie zanesen až v roce 1968. Před 2. světovou válkou byl daný termín používán jen $\mathrm{v}$ matematickém prostředí a v dílech osvícenců Johna Lockea a Davida Humea. Locke označoval identitou: „....pokračování života navzdory neustále prchlivosti hmotných částic" (Locke dle Gleason, 1983: 919).

${ }^{5}$ Jedním z výrazů poválečné orientace amerických vědců na otázku jedincova působení ve společnosti a na téma atomizace společnosti bylo i „znovuobjevení "Tocquevilla, jehož dílo se v 50. letech 20. století stalo díky své nadčasovosti opět velmi oblíbené a obdivované (Gleason, 1983: 927).
} 
dospívání, v níž rezonuje jak dimenze vývoje individuální osobnosti (ego-identita), tak vůbec poprvé - a v tom lze hledat zárodky pozdějšího interdisciplinárního rozmachu daného konceptu - i dimenze dialektického vztahu jedince ke svému okolí (Gleason, 1983: 912 - 913; Wurgaft: 1995: 69). ${ }^{6}$

Od Eriksonova uvedení jinak Leibnizova7 matematického termínu identita do sociálně-vědního diskursu a od dalších prvotních prací a konceptů sociální psychologie (např. Allport, 1954; Goffman, 1959; Tajfel, 1959; Turner, 1978; Stryker, 1967, aj.), které s tímto termínem pracovaly, popularizovaly jej, nebo často odkazovaly na předchůdce a zástupce symbolického interakcionalismu Herberta Meada, Charlese Hortona Cooleyho a Herberta Blumera, na Durkhaimův koncept kolektivního vědomí, nebo na teorii rolí a teorií referenčních skupin Roberta Mertona, ovšem pojem označující "totožnost" významně přesáhl pomyslné hranice ego-psychologických a sociálně-psychologických paradigmat a v různých modifikacích se rozšiřil do většiny společensko-vědních disciplín (srov. Gleason, 1983: 916 - 918; Weigert, 1986; Hogg, Terry, White, 1995: 256; Huddy, 2001: 127; Passi, 2003: 475; Abdelal a kol., 2006: 696). Aktuálně proto můžeme číst ve vztahu $\mathrm{k}$ identitě nejen odborné psychoanalytické články o lacanovském imaginárnu ${ }^{8}$, ale můžeme si rovněž zakoupit nespočet antropologických knih o etnických identitách, nebo se můžeme setkat se sociologickými studiemi o konstrukcích skupinové identity. Stejně tak si ale lze vyslechnout historickou přednášku o formování národních identit, shlédnout na Youtube video o identitách třísektorové ekonomiky, nebo navštívit politologickou konferenci na téma „Evropská identita“. Jak hned v prvním odstavci odkazovaného textu Beyond "Identity“ uvádějí Brubaker s Cooperem (2000: 1), a jak zároveň kvantifikuje ve své studii Fearon (1999: 1), společenská věda doslova propadla pojmu identita. ${ }^{9}$ Čemu že to ale vlastně propadla?

\footnotetext{
${ }^{6}$ Erikson v návaznosti na Freuda spojil koncept „ega“ a „identity“ k označení komplexní organizace identifikací a introjekcí (tedy dohromady procesu internalizace), čehož je výsledkem organizované sebepojetí jedince (schopnost být neustále „tím samým“ pro sebe i jiné). Vedle „ego-identity“ pak staví koncept ",self-identity“ , kterým označuje složku aktivního hodnocení sebe sama. Identita jedince se pak utváří ve třech základních stádiích: premorální, ideologické, etické; přičemž klíčový je pozdně adolescentní věk (sebe)nejistoty, již Erikson označil jako „krizi identity“ (Erikson, 1968). V 60. letech 20. století, tedy v době mezigeneračních (ale i rasových) sporů v USA, evropských celospolečenských otřesů, se Eriksonova tvorba o identitě postupně stala jakousi mantrou, která dokázala velmi často nalézat inovativní odpovědi na aktuální otázky o interakci a dialogu jedince se sebou samým i se společností.

7 Gottfried Wilhelm Leibniz (1646 - 1716) v rámci své „monadologie“ hovoří o identitě v souvislosti s tzv. "principem identity nerozlišitelných", podle něhož, existují-li dva kvalitativně identické předměty, jsou numericky totožné navzájem a jde proto o tentýž předmět.

${ }^{8}$ Lacan ve své psychoanalýze označuje imaginárnem proces, v němž vzniká Já a jeho identita. $\mathrm{V}$ rámci tohoto procesu přijímá jedinec obrazy (imaga) sebe sama a "těch druhých“ (tzv. stadium zrcadla).

${ }^{9}$ James D. Fearon (1999: 1) ve svém textu "What is Identity (Us We Now Use the Word)?“ uvádí, že od roku 1981 do roku 1995 se počet disertačních prací, v jejichž abstraktu figuroval pojem identita, takřka ztrojnásobil (ze 709 na 1911), přičemž průměrný meziroční nárůst množství takových prací od roku 1986 činil $12 \%$.
} 
Ze skutečnosti, že koncept identity postupně prostoupil do většiny sociálně-vědních disciplín a spolu s tím se na něj nabalovaly nové či naopak eliminovaly pưvodní („eriksonovské“) významy, vyvstává jistý definiční problém a snad i aktuální zmatečnost a vágnost samotného pojmu identita (srov. Gleason, 1983: 914; Kohli, 2000: 114; Aguiar a kol., 2010: 263). Přesto lze nalézt několik společných vztyčných pilířu a atributů, které se často při konceptualizaci identity opakují a jsou velkou částí sociálněvědní obce zdůrazňovány, a sice: modularita, kontextuální (resp. situační a relační) podmíněnost, pocit koherence a kontinuity, dynamický a mnohovrstevný charakter, a $\mathrm{v}$ neposlední řadě také původ v dialektickém vztahu mezi jedincem a společností. $\mathrm{Na}$ základě interpretačního př́stupu jednotlivých badatelů $\mathrm{k}$ těmto zmíněným komponentám pak Brubaker s Cooperem (2000: 6 - 8) rozeznávají pět nejčastějších pojetí identity: 1) identita jakožto základna a zdroj sociální či politické akce; 2) identita jakožto stejnost členů určité kolektivity, přičemž tato stejnost může být chápána objektivně (totožnost sama o sobě) či subjektivně (představa totožnosti, nebo příslušnosti k určité skupině); 3) identita coby fundamentální neměnné jádro osobnosti; 4) identita jakožto výsledek sociálně-politického jednání; 5) identita vnímaná v duchu Foucaultovy postmoderní filosofie jako prchlivý a fragmentovaný produkt soutěžících diskursů. V této klasifikaci přitom evidentně rezonuje i jednodušší a tradičnější členění na esencialistický (primordialistický) a (re/de)konstruktivistický přístup k utváření pomyslných hranic mezi Já a Ty, nebo My a "Ti druzí“ (Brubaker a Cooper hovoří o "slabém“ a „silném“ pojetí identity). Nakolik jsou tyto hranice neměnnou objektivní a přirozenou daností, sociálním konstruktem, nebo výzvou k dekonstrukci, není však dle mého soudu jen otázka badatelského uchopení samotné identity, ale $\mathrm{v}$ širší perspektivě rovněž otázka pojetí úlohy/smyslu společenských věd a jejich vztahu ke každodenní sociální praxi.

Zastánci v posledních dekádách slábnoucího esencialistického přristupu stále věří v objektivní existenci své bohyně Identity a jsou přesvědčeni o tom, že je sociální vědec zcela odloučen od zkoumaného předmětu, je nezávislý, schopný objektivně nazř́it podstatu věcí a realitu samu o sobě - tak, jak jest (episteme). V rámci tohoto naturalistického pojetí sociální reality, které koresponduje s newtonovským př́istupem k fyzickému světu, je identita vymezena jako totožnost - domněle - objektivně př́tomných znaků (např. rasa, jazyk, etnicita, pohlaví, třída, národnost, etc.). Subjektivní sebe-identifikace jedinců by pak těmto objektivním znakům (kategoriím) měla v každodenní praxi odpovídat, a pakliže tomu tak není, jedná se dle primordialistů jen o laické subjektivní zdání (doxa) nebo anomálie, které jsou více či méně př́imou výzvou k inkluzivní či exkluzivní politice identity, jenž má tyto „úchylky od normality“ eliminovat, minimalizovat, nebo v lepším př́ípadě alespoň "tolerovat", nikoliv je však respektovat jako individuální volbu. Představme si kupříkladu jedince, který vykazuje některé domněle objektivní znaky španělství (mluví výborně španělsky, narodil se v Barceloně, má španělské rodiče, jeho etnicita 
se zdá být španělskou, jeho genetický kód je velmi podobný s kódem nalezeným u pozůstatků Iberů, údajných španělských předků), ale zároveň se sám necítí být Španělem, nýbrž výlučně Kataláncem. A obdobně bychom mohli argumentovat na příkladu mužů (definovaných jako vlastníků objektivně pozorovatelných biologických znaků a z nich "přirozeně“ plynoucích sociálních rolí), kteří se cítí být ženami - tedy tzv. transgenderů, apod. Primordialisté mají v př́ípadě těchto nesouladů jasno, daný jedinec je jimi označen za Španěla/muže, bez respektu k jeho sebeidentifikaci. Toto upřednostnění objektivní identifikace (resp. kategorizace) má ovšem $\mathrm{v}$ součinnosti s autoritou a privilegovaným postavením vědy $\mathrm{v}$ celospolečenském diskursu velký potenciál ke zneužití - společenská věda má zde velmi blízko k tomu, aby se stala nejen nositelkou objektivního vědění, ale také vskutku „nezávislou“ služkou politiky, jak bylo ostatně možné zaznamenat u etnografie 19. a 20. století, u „odborné“ literatury kolonialismu, u geopolitiky, marxistické ekonomie, oficiální (nacionální) historiografie, atd.. (Barša, 2006: 23 - 26)

Konstruktivisté, kteří jsou aktuálně na společensko-vědním poli zřejmě nejpočetněji zastoupenou skupinou, si jsou vědomi toho, že jejich bohyně Identita není jsoucí sama o sobě, ale že je „jen“ smyšlenou součástí mýtů produkujících sociální realitu a ospravedlňujících určité jednání konkrétních aktérů. Toto prozření je nicméně na druhé straně vykoupeno faktickým vzdáním se veškerých epistemologických nástrojů, které umožňují rozpoznávat pravdivé od nepravdivého, či správné od nesprávného, nebot' se konstruktivismus zříká objektivních standardů hodnocení a ve své krajní poststrukturalistické formě trochu podléhá vlastnímu (auto)destrukčnímu potenciálu a občasně zabředá do bažin relativismu. V závislosti na tom, jak je $\mathrm{k}$ identitě coby k mýtu přistupováno, lze pak vyčlenit dvě základní, byt’ zjednodušující kategorie výzkumníků: rekonstruktivisté a dekonstruktivisté. ${ }^{10}$ Principiální rozdíl mezi nimi spočívá v tom, že "ti první" mýtus o identitě pouze převypravují a berou jej jako

\footnotetext{
10 Oba proudy stavějí na teorii sociálně konstruované reality, za jejíž společensko-vědní (tedy nikoliv hlubší filozofickou, resp. hermeneutickou a fenomenologickou) platformu lze považovat dílo Petera L. Bergera a Thomase Luckmanna "The Social Construction of Reality" z roku 1966. V jeho duchu konstruktivisté přistupují $\mathrm{k}$ identitě jako $\mathrm{k}$ sociální reálii, která je konstituována jakožto představa/dojem jáství nebo př́slušnosti $\mathrm{k}$ určité kolektivitě $\mathrm{v}$ procesu neustále institucionalizujících se a habitualizujících se identifikací. Tyto představy/dojmy jsou nepřetržitě redefinovány v průběhu celoživotního socializačního procesu, v jehož rámci si jedinec osvojuje jistý sociální, diskursivní a symbolický řád (přijímá jakousi prefiguraci „přirozenosti“) a spolu s ním i určité sebe-porozumění a kolektivní vědomí. (Berger, Lukmann, 1999: 55, 62 a 103; Löwenstein, 1997: 62)

Samotný socializační proces byl na poli společenských věd nazírán z mnoha teoretických perspektiv. Funkcionalismus kupř́kladu vnímal socializaci jako strategii ke „zdařilé výchově“. V obdobném duchu ji pojímal i tzv. reprodukční model, pro nějž byla mechanismem sociální kontroly. Teprve konstruktivistický př́stup ale přidělil jedinci v procesu socializace aktivní úlohu a přestal jej pojímat striktně jako objekt okolního působení (viz Barša, 2006: 29); ačkoliv - a to se stalo předmětem pozdější kritiky zástupců tzv. interpretativního modelu - se i nadále drží termínu „socializace“, který a priori budí dojem pokračování asymetrického vztahu mezi individuem a společností. Někteří sociologové učení a dětské výchovy (např. William Corsaro) v této souvislosti navrhují nahrazení termínu „socializace“ pojmem „interpretativní reprodukce“ (Corsaro, 1997).
} 
nutnou - ač zkonstruovanou - intersubjektivně sdílenou součást sociální reality, zatímco "ti druzí" se $\mathrm{k}$ danému mýtu stavějí v duchu západního racionalismu kriticky a volají po jeho destrukci (Barša, 2006: 22).

Jinými slovy řečeno, podle tzv. rekonstruktivistů by měl sociální vědec analyzovat naturalizace ideologií a identit, neměl by se však snažit kritizovat a měnit sociální realitu (k domněle lepšímu), nýbrž měl by „neutrálně“ (neutrálně pouze z pohledu společenské vědy, nikoliv však celé sociální praxe) zachycovat její obraz. Tímto „neutrálním“ př́stupem nicméně rekonstruktivisté $\mathrm{v}$ zásadě přistupují na recyklování mýtu o té či oné identitě a mnohdy jej dokonce apologeticky přiživují a vytvářejí z něj to, co je v sociální antropologii a sociologii občas označováno „druhou přirozeností“, nebot' považují př́slušnost $\mathrm{k}$ jistým konstruovaným kolektivitám za přirozenou součást lidského bytí a samotným hovořením o identitách uchovávají zdání jejich přirozenosti. Naopak tzv. dekonstruktivisté mají za to, že společenské vědy by neměly pouze vykládat sociální realitu, ale měly by $\mathrm{k}$ ní přistupovat navýsost kriticky a přispívat $\mathrm{k}$ její změně ve smyslu emancipování a aktivního osvobozování jedince od jej obklopujících naturalizovaných ideologií. Tím však dekonstruktivismus opětovně staví sociální vědu do normativní, leckdy až politické role autority schopné rozeznat "pravdivé“ a "společensky potřebné“. Je-li nicméně každá identita takto apriorně označena za falešnou výslednici konstrukčních procesů vyzývající $\mathrm{k}$ dekonstrukci, nedochází tím nepř́mo $\mathrm{k}$ naturalizaci individualismu? Není výsledkem onoho "osvobozování člověka představa univerzální přirozenosti každého jednotlivce, již sdílí s př́slušníky lidského druhu? Nestávají se mnohé malé mýty o topicky, rodově, profesně, konstitučně a jinak definovaných identitách, jedním velkým vyprávěním o identitě lidské (Barša, 2006: 29)? Nesnaží se dekonstruktivismus, byt’ mnohem sofistikovaněji, jak poznamenává Calhoun (1994: 17), o pro západní civilizaci tolik př́značné esencialistické hledání lidské substance - jádra, které sám Derrida tolik kritizoval (viz Szaló, 2003: 17)?11 Jak z mého pohledu trefně uvádí J. Hillis Miller (dle Petrusek, 1995: 245), dekonstrukce tak trochu dekonstruuje samu sebe.

Jak jsem výše demonstroval, a to především prostřednictvím reinterpretace pro svou stř́zlivost a sebereflexi vynikající stati "Konstruktivismus a politika identity“ od Pavla Barši, ani jeden ze tří základních přístupů ke konceptu identity, a potažmo k sociální realitě jako takové, se neobejde bez problémů, které je nutné nazřít v kritické perspektivě. Vedle vágnosti a zmatečnosti pojmu identita je zřejmé, že při jeho esencialistickém uchopování se může neblaze promítat do sociální praxe ve smyslu

11 Csaba Szaló (2003: 17) poukazuje na Derridovu kritiku hegemonie západní kulturní reprezentace lidských bytostí coby osob s jistým centrem/jádrem, s autentickým vnitřním Já - identita je tak pojímána esencialisticky jako určité jádro individuálního bytí, které se vymyká dynamice neutralizovaných, tedy upozad'ovaných struktur. Podle Barši (2009: 29) ovšem při scientistické dekonstrukci kolektivních identit dospíváme právě k závěru o formování „přirozenosti“ individualismu - lidského jádra př́tomného ve všech osobách. 
legitimování popírání jinakosti a proměnlivosti jedinců, stejně tak jako ve smyslu poplatnosti inkluzivním a exkluzivním politikám. Při konstruktivistickém pojímání identita pro změnu sémanticky nekoresponduje s mnohorozměrnou, procesuelní a fluidní povahou, na níž sociální vědci neúnavně odkazují a navíc se v rámci tzv. rekonstruktivismu fakticky stává "druhou přirozeností". Konečně při dekonstruktivistickém zacházení je identita rozmělňována natolik, že se pod nálepkou „osvobození subjektů a individualit" nenápadně formuje „přirozená“ lidská substance individualismu - jakási identita "bezidentitních“ - a v tomto smyslu je dekonstruktivismus tak trochu (nechtěným?) návratem $\mathrm{k}$ esencialismu. $\mathrm{V}$ této souvislosti je ale nutné se ptát, jak by měl tudíž sociální vědec koncept identity uchopit. A měl by se o to vưbec snažit? Neměl by dát raději na výzvu Brubakera a Coopera a jejich přitakávačů a vydat se „za identitu“ směrem $\mathrm{k}$ alternativním a vhodnějším konceptům, které dokážou odborně postihnout zamýšlené obsahy problematizovaného termínu, aniž by měly tak silný přesah do sociální praxe? A je toto odloučení od tak rozšířeného a ceněného konceptu vůbec představitelné?

\section{Představa o sociální vědě bez identity}

Představme si na okamžik, že by se společenské vědy jednoho rána ocitly bez své oblíbené bohyně Identity, která jim po dlouhá léta napomáhala a dodnes napomáhá zodpovídat celou řadu otázek o vztahu jedince s jej obklopující společností a prostředím. Pro mnohé sociální vědce je to dozajista děsivá a nemyslitelná idea (viz Tilly, 1996: 7; Hall, 2000: 15). Jimi dlouhodobě užívaný analytický koncept, který vychází z odporu k mýtu o univerzální lidské racionalitě; jejich letitý pracovní nástroj zkoumání a přístupu k sociální realitě; veškeré výstupy jejich nepochybně koncepční a systematické výzkumné činnosti (ty tisíce knih, desetitisíce odborných článků a konferenčních příspěvků); a pro některé dokonce badatelská vášeň; to vše by mohlo ztratit své pojmenování a $\mathrm{k}$ němu pojící se totožnost - ano, totožnost! A ba co víc, nejeden $z$ vědců by mohl přijít o své úrodné výzkumné pole, které ho v té či oné míře živí (někdy mu spíše umožňuje přežívat), pročež je často v jeho zájmu o něj pečovat, rozšiřovat jej a př́ípadně jej také bránit (třeba i mlčením o jeho nedostatcích). Dost možná by tak právě sociální vědci jako první na pádnou otázku Stuarta Halla (2000: 15) Who needs „Identity“?, křičeli odpověd” „My“ - manifestujíce svou vlastní profesní identitu.

Na předcházejících stránkách jsem několikrát poukazoval na některé z problémů konceptu identity: a) pro sociální praxi nebezpečné a pro sociální vědu nevhodné tendence k jejímu zvěcňování; b) zastírání jinakostí identifikovaných/identifikujících pod unifikační etiketou totožnosti, resp. apriorní předvídání, že procesy identifikace povedou k tvorbě představy stejnosti; c) až př́lišná vágnost pojmu, která na jedné straně prakticky umožňuje jeho „vše-použitelnost“, na straně druhé předpokládá vždy důslednou konceptualizaci; d) sémantický rozpor zpodstatňujícího termínu 
„identita“ s jeho efemerním, procesuálním či performativním pojetím. Jedním z velkých nedostatků užívání daného konceptu $\mathrm{v}$ sociálně-vědní praxi je ale i skutečnost, že je s ohledem na svou nadprodukci nekriticky přijímán samotnými vědci jako něco samozřejmého, neodmyslitelného, sloužícího k automatické aplikaci bez hlubší reflexe a operacionalizace. Mnozí badatelé (včetně zástupců konstruktivistických proudi̊) vskutku berou identitu "tak jak je“ - identita jakožto analytický koncept je pro ně velmi často v rámci společensko-vědního diskursivního pole přirozeností. To je přitom zajímavý paradox, nebot' zatímco na poli sociální praxe je identita (ve smyslu označované totožnosti jáství či příslušnosti k jisté kolektivitě) z konstruktivistického pohledu některými badateli zpochybňována, resp. zbavována podstaty a přirozenosti, tak na půdě sociální vědy je identita (coby označující pro totožnost jáství či př́islušnost $\mathrm{k}$ jisté kolektivitě) velmi často těmi samými vědci brána jako objektivní danost, o níž netřeba dále pochybovat. Jakoby pravidla sociální konstrukce reality platila pro některé (tedy rozhodně ne všechny!) autory jen mimo společensko-vědní obec, která pro ně zůstává - v rozporu s tím, co bylo řečeno dříve, tedy, že je vědec neoddělitelnou součástí zkoumané sociální praxe - objektivní a k sobě samé nekritickou sférou skutečného poznání (episteme).

Na základě výše uvedené tematizace pojmu identita dospívám k závěru, byt' s pokorou a bez nárokování si jeho obecné či dokonce konečné platnosti, že je daný společensko-vědní koncept zbytný a nahraditelný. To však dozajista neznamená, že by neměly být analyzovány aspekty jako je sama politika identity, jakési identitární projekty, nebo společenský a politicky diskurs identity, které jsou běžně přitomné ve zkoumané sociální praxi. K takovému rozboru by však bylo vhodnější využívat jiných konceptů. Identita by měla být jen předmětem a nikoliv nástrojem (a v některých případech dokonce líbivou prodejní značkou) výzkumu. Zároveň je ale třeba vnímat i skutečnost, že je pojem ve vědecké obci natolik zažitý a má za sebou tolik užitečné práce, že nebude snadné jej jen tak prostě „ponechat", byt' ve jménu větší vědecké preciznosti. Mám ovšem za to, že je nutné se o to postupně pokoušet a minimálně je třeba přistupovat na společensko-vědním poli $\mathrm{k}$ identitě $\mathrm{z}$ kritické perspektivy a dávat následně prostor pro nové, nebo staronové koncepty, které alespoň částečně eliminují problematičnost daného pojmu. Identita, dle mého úsudku, totiž v posledních letech začíná společenským vědám spíše škodit, než jim přinášet užitek.

\section{Závěr}

Ve společenských vědách se čas od času objeví pojem, který se postupně stane natolik užívaným a líbivým, že si jej posléze přisvojí i každodenní sociální praxe a naplní jej novými významy a tím jej fakticky znehodnotí pro budoucí badatelskou činnost. Identita, zdá se, částečně doplácí na svou akademickou popularitu a díky 
velkému potenciálu vymezovat a rozdělovat přímo vyzývá k politickému zneužití. Jeli přitom sociální věda - byt' v jisté míře autonomní - součástí zkoumané sociální reality a nikoliv zcela nezávislou a objektivní sférou konečného a pravého poznání, měla by brát na sebe svůj díl společenské odpovědnosti a zpětně reflektovat možné (pozitivní i negativní) dopady vlastních výstupů. Zpolitizované teorie a koncepty by měly být opouštěny a očištovány už jen proto, aby je zaštitující autorita vědy neposkytovala oporu jejich dalšímu případnému zneužívání. Je třeba ale mít na paměti i jiné a snad věcnější nedostatky konceptu identity.

Vedle sémantického problému a terminologické vágnosti pojmu jsem na předcházejících stránkách poukazoval, že mnozí (tedy opětovně zdůrazňuji, že nikoliv všichni) autoři nekriticky přejímají koncept identity jako samozřejmost, a to bez ohledu na to, zda s ním následně pracují z pozice primordialismu či konstruktivismu. Každému uchopování jakéhokoliv společensko-vědního konceptu, tedy i identity, by ale dle mého uvážení měly předcházet $\mathrm{v}$ běžné sociální praxi často opomíjené dětské otázky "a proč?“, které nejsou zatížené dospělým pocitem (domnělé) přirozenosti okolních věcí a které jsou na počátku každé kritické reflexe okolního světa. Svědomitý badatel musí mít $\mathrm{v}$ sobě velký kus takové dětské zvídavosti a na každou jemu předkládanou odpověd” by se měl opětovně a neustále ptát „a proč?“. Čím více si takových otázek bude pokládat, tím méně samozřejmý mu okolní svět bude připadat, a tím více o něm bude pochybovat.

Pochyby jsou pro mne výchozím bodem poznání a „jistota“ je jeho limitou. Jelikož je ale na druhé straně každé poznání, jak zdơrazňoval Wittgenstein (1969: 378), v konečném důsledku založeno také na (společenském, vědeckém, politickém, aj.) uznání, nejde pouze o záležitost jakéhosi prozření jedince, ale rovněž „těch druhých“, kteří jej obklopují. A nejinak je tomu $\mathrm{v}$ případě zde problematizovaného termínu identita. Uznává-li velká část společensko-vědní obce, k nevoli Brubakera s Cooperem, svou oblíbenou bohyni jakožto vhodný a užitečný analytický nástroj označující jisté přechodně stabilizované struktury, pak - v případě Vašeho nesouhlasu - nezbývá, než toto „uznané poznání“ zároveň respektovat i podrobovat další kritice a stavět před něj logickou argumentaci a relevantní otázky „proč?“: Proč bychom měli pracovat s konceptem, který zjevně svádí k politickému zneužívání? Proč bychom měli výraz stabilního uplatňovat $\mathrm{k}$ označení procesuálního? Proč bychom něco sdíleného a společného měli apriorně a totalitně označovat „identickým“? Proč bychom za určitým konáním člověka měli hledat právě identitu? A proč jako sociální vědec potřebuji tento podivuhodný pojem? Proč identita?

Pakliže bude vědec svědomitě hledat odpovědi na tyto otázky a na základě poctivé argumentace dojde k závěru, že má pojem identita ve společenských vědách své místo, necht' jej používá. Dojde-li badatel při zodpovídání uvedených otázek k opačnému závěru, tedy že by bylo vhodnější si ve jménu větší preciznosti a společenské 
odpovědnosti osvojit jiný a vhodnější koncept, at' tak učiní. V žádném př́ípadě by ale výzkumník neměl nechávat zmíněné otázky bez povšimnutí a odpovědi na ně nekriticky považovat za samozřejmé. Právě ona „samožrejmost" totiž značí pomyslnou a mnohdy nejasnou hranici, za níž se relativně autonomní společenská věda stává politikou. 


\section{Bibliography}

Abdelal, R., et. al. (2006). Identity as a Variable. Perspectives on Politics, Vol. 4, No. 4, (December, 2006), $695-711$.

Allport, G. W.: (1954). The Nature of Prejudice. Addison-Wesley, Cambridge.

Assman, J.: (2001). Kultura a pamět'. Písmo, vzpomínky a politická identita v rozvinutých kulturách starověku. Prostor, Praha.

Austin, J. L.: (2000). Jak udělat něco slovy. Filosofia, Praha.

Barša, P.: (2006). Konstruktivismus a politika identity. AntropoWebzin, č. 1, (2006), $21-35$.

Berger, P. L. - Luckmann, T.: (1999). Sociální konstrukce reality. Pojednání o sociologii vědění. CDK, Praha.

Bergson, H.: (2003). Hmota a pamět'. Oikoymenh, Praha.

Bourdieu, P.: (2010). Sociální prostor a symbolická moc. Prednáška v San Diegu, březen 1986. In Cahiers du CEFRES, cervenec 2010, 1 - 12.

Brubaker, R. - Cooper, F.: (2000). Beyond „Identity“. Theory and Society, 29, (2000), 1 $-47$.

Butler, J.: (1993). Bodies that Matter. On the Limits of "Sex". Routledge, New York, London.

Corsaro, W. A.: (1997). The Sociology of Childhood. Pine Forge Press, Thousand Oaks.

Durkheim, E.: (1926). Pravidla sociologické metody. Praha, Orbis.

Erikson, E. H.: (1963). Childhood and Society. Norton, New York.

Ezzy, D.: (1998). Theorizing Narrative Identity: Symbolic Interactionism and Hermeneutics. The Sociological Quarterly, Vol. 39, No. 2, (Spring, 1998), 239 - 252.

Fearon, J. D.: (1999). What is Identity (As We Now Use the Word)? [online]. Dostupné na: https://www.stanford.edu/group/fearon-research/cgi-bin/wordpress/wpcontent/uploads/2013/10/What-is-Identity-as-we-now-use-the-word-.pdf (24. 2. 2014(

Feyerabend, P. K.: (2001). Rozprava proti metodě. Aurora, Praha. 
Foucault, M.: (2009). Zrození biopolitiky. CDK, Brno.

Foucault, M.: (2000). Dohližet a trestat. Dauphin, Praha.

Fulka, J.: (2002). Od interpelace k performativu (Feminismus a konstrukce rodové identity). Sociální studia, č. 7, (2002), 29 - 50.

Gleason, P.: (1983). Identifying Identity: A Semantic History. The Journal of American History, Vol 69, No. 4, (March 1983), 910 - 931.

Goffman, E. (1974). Frame Analysis. An Essay on the Organization of Experience. Harper and Row, New York.

Goffman, E.: (1959). The Presentation of Self in Everyday Life. Doubleday Anchor Books, Garden City.

Halbwash, M.: (2010). Kolektivní pamět. Sociologické nakladatelství, Praha.

Hall, S. (1996). Who needs „Identity“? from du Gay, P. Evans, J. and Rodman (eds.). Identity: a reader, $15-30$.

Hogg, M. A. - Terry, D. J. - White, K. M.: (1995). A Tales of Two Theories: A Critical Comparsion of Identity Theory with Social Identity Theory. Social Psychology Quarterly, Vol 58, No. 4, (1995), 255 - 269.

Huddy, L.: (2001). From Social to Political Identity: A Critical Examination of Social Identity Theory. Political Psychology, Vol. 22, No. 1, (March, 2001), 127 - 156.

Kohli, M.: (2000). The Battlegrounds of European Identity. European Societies, Vol. 2, No. 2, (2000), 113 - 137.

Le Goff, J.: (2007). Pamět’ a dějiny. Argo, Praha.

Levinás, E.: (1997). Totalita a nekonečno. Oikoymenh, Praha.

Lowenstein, B. W.: (1997). My a ti druzí. Doplněk, Brno.

Melucci, A.: (1995). The Process of Collective Identity. In Johntson, H. Klandermans, B., Social Movements and Culture. University of Minnesota Press, Minneapolis.

Nora, P. (2008). Entre Memoria e Historia. A problemática dos lugares. In Rilla, J.: Pierre Nora en Les lieux de mémoire. Trilce, Montevideo. 
Novotný, D.: (2010). Identita $v$ antropologii (kritický pohled) [online]. http:/ / poznamkypodcarou.blogspot.cz/2010/08/identita-v-antropologii-kritickypohled.html (24. 2. 2014)

Olšovský, J.: (2011). Slovník filozofických pojmů současnosti. 3., rozšírené a aktualizované vydání. Grada Publishing, Praha.

Paleček, M.: (2008). Identita - podivný pojem. AntropoWebzin, č. 1, (2008), 62 - 71.

Paasi, A.: (2003). Region and Place: Regional Identity in Question. Progress in Human Geography, Vol. 27, No. 4, (2003), 475 - 485.

Petrusek, M.: (1995). Dekonstruovaný informátor a sociální konstrukce českého národa. Sociologický časopis, Vol. 31, No. 1, (1995), 245 - 252.

Ricouer, P.: (2000). La Memoria, la Historia, el Olvido. Fondo de Cultura Economica, Buenos Aires.

Stryker, S.: (1968). Identity Salience and Role Performance: The Importace of Symbolic Interaction Theory for Family Research. Journal of Marriage and the Family, č. 30, (1968), $58-64$.

Szaló, C.: (2003). Sociologie formování sociálních identit. In Szaló, C. - Nosál, I. (eds.), Mozaika v rekonstrukci, IIPS, Brno, 13 - 36.

Tajfel, H.: (1959). Quantitative judgement in social perception. British Journal of Psychology, 50, (1959), 16-29.

Tilly, Ch.: (1996). Citizenship, Identity and Social History. Cambridge University Press, Cambridge.

Todorov, T.: (1998). Pamět' před historií. In Antologie francouzských společenských věd: Politika paměti. Cahiers du Cefres, 17, 33 - 46.

Turner, R. H.: (1978). The Role and the Person. American Journal of Sociology, 84, (1978), 1 - 23.

Weigert, A. J. et al.: (1986). The Social Production of Identity: Metatheoretical Foundations. The Sociological Quarterly, Vol. 27, No. 2, (1986), 165 - 183.

Wittgenstein, L.: (1969). On Certainty. Blackwell, Oxford.

Wurgaft, L. D.: (1995). Identity in World History: A Postmodern Perspective. History and Theory, Vol 34, No. 2, (May, 1995), 67 - 85. 


\section{E-LOGOS}

ELECTRONIC JOURNAL FOR PHILOSOPHY

Ročník/Year: 2014 (vychází průběžně/ published continuously)

Místo vydání/Place of edition: Praha

ISSN 1211-0442

Vydává/Publisher:

Vysoká škola ekonomická v Praze / University of Economics, Prague

nám. W. Churchilla 4

Czech Republic

13067 Praha 3

IČ: 61384399

Web: http://e-logos.vse.cz

Redakce a technické informace/Editorial staff and technical information:

Miroslav Vacura

vacuram@vse.cz

Redakční rada/Board of editors:

Ladislav Benyovszky (FHS UK Praha, Czech Republic)

Ivan Blecha (FF UP Olomouc, Czech Republic)

Martin Hemelík (VŠP Jihlava, Czech Republic)

Angelo Marocco (Pontifical Athenaeum Regina Apostolorum, Rome, Italy)

Jozef Kelemen (FPF SU Opava, Czech Republic)

Daniel Kroupa (ZU Plzeň, Czech Republic)

Vladimír Kvasnička (FITT STU Bratislava, Slovak Republic)

Jaroslav Novotný (FHS UK Praha, Czech Republic)

Jakub Novotný (VŠP Jihlava, Czech Republic)

Ján Pavlík (editor-in-chief) (VŠE Praha, Czech Republic)

Karel Pstružina (VŠE Praha, Czech Republic)

Miroslav Vacura (executive editor) (VŠEE Praha, Czech Republic) 